\title{
A conceptual model of solute acquisition by Alpine glacial meltwaters
}

\author{
MARTYN TRANTER, \\ Department of Geography, University of Bristol, Bristol BS8 1SS, England \\ Giles BRown, \\ Department of Geoography, University of Cambridge, Cambridge CB2 3EN, England \\ ROBERT RAISWELL, \\ Department of Earth Sciences, University of Leeds, Leeds LS2 9JT, England \\ MARTIN SHARP, \\ Department of Geography, University of Cambridge, Cambridge CB2 3EN, England \\ ANGELA GURNELL \\ Department of Geography, University of Southampton, Southampton SO9 5NH, England
}

\begin{abstract}
Solute acquisition by Alpine glacial meltwaters is the result of the coupling of different pairs of reactions, one of which usually involves dissolved gases. Hence, the availability of atmospheric gases to solution is an important control on the composition of glacial meltwaters. The chemical compositions of the two main components of the bulk meltwater, quick flow and delayed flow, are dominated by different geochemical processes. Delayed flow waters are solute-rich and exhibit high $p\left(\mathrm{CO}_{2}\right)$ characteristics. The slow transit of these waters through a distributed drainage system and the predominance of relatively rapid reactions, such as sulphide oxidation and carbonate dissolution, in this environment maximize solute acquisition. Quick-flow waters are dilute, both because of their rapid transit through ice-walled conduits and open channels, and because the weathering reactions are fuelled by relatively slow gaseous diffusion of $\mathrm{CO}_{2}$ into solution, despite solute acquisition being dominated by rapid surface exchange reactions. As a consequence, quick flow usually bears a low or open-system $p\left(\mathrm{CO}_{2}\right)$ signature. Bulk meltwaters are more likely to exhibit low $p\left(\mathrm{CO}_{2}\right)$ values when suspended-sediment concentrations are high, which promotes post-mixing reactions. This conceptual model suggests that the composition of both quick flow and delayed flow is likely to be temporally variable, since kinetic, rather than equilibrium, factors determine the composition.
\end{abstract}

\section{INTRODUCTION}

The chemistry of (bulk) meltwaters draining from Alpine glaciers may enable seasonal variations in water routing through the hydrological system to be inferred, provided that realistic estimates can be made of the compositions of waters which have followed different flowpaths through the glacier drainage system (Collins, 1979a, b, 1981; Sharp, 1991). Seasonal variations in water routing and in subglacial water pressure are thought to influence both glacier motion (Iken, 1981; Bindschadler, 1983; Iken and others, 1983; Lliboutry, 1983; Weertman and Birchfield, 1983 ) and the tapping of suspended-sediment sources from subglacial environments (Gurnell and Fenn, 1984; Gurnell, 1987; Collins, 1989). Earlier consensus regarding the chemical composition of the two or more components which constitute the bulk meltwaters (Collins, 1978; Oerter and others, 1980; Gurnell and Fenn, 1984) is that they may be assumed to be relatively constant throughout the ablation season (Collins, 1978, 1979b). However, recent work challenges this assumption (Tranter and Raiswell, 1991; paper in preparation by M. Sharp and others). Hence, it seems timely to explain how chemicalweathering reactions in dilute solutions give rise to meltwater chemistry which is more variable than hitherto supposed.

The notion that the composition of each component may be constant arises because the existing glaciological literature tends to focus on individual, rapid weathering reactions, such as so-called "ion exchange" (Lemmens and Roger, 1978), in isolation from the reactions which furbish protons, or $\mathrm{H}^{+}$(aq). A supply of protons is 
usually required for the chemical weathering of glacial flour and may be generated by the relatively slow diffusion of gaseous $\mathrm{CO}_{2}$ into solution (Raiswell, 1984). We show below that it is often the coupling of such reactions, rather than the exchange reaction alone, which results in solute acquisition by glacial meltwaters.

Our purpose in this paper is to outline a conceptual model of solute acquisition by Alpine glacial meltwaters, which identifies the likely sources of the solute, details the key chemical-weathering reactions and outlines the likely linkages betweeen these reactions. Finally, we identify the relative rates of the reactions and show how meltwater chemistry bears the fingerprint of the differing soluteacquisition rates. We illustrate the text with examples of Alpine meltwater chemistry, mainly from Haut Glacier d'Arolla, Switzerland. Details of sample collection and treatment may be found in Brown (1991) and Brown and Tranter (1990).

\section{THE COMPONENTS OF BULK MELTWATER - QUICK FLOW AND DELAYED FLOW - AND SUBGLACIAL DRAINAGE ROUTES}

Bulk meltwaters are believed to be largely composed of two components, termed the "subglacial" and "englacial" components by Collins (1978, 1979b). Both components are ultimately derived from surface-snow and ice melt. Less significant amounts of water can be derived from rainfall, ground water, melting due to viscous dissipation in deforming ice, and geothermal melting (Collins and Young, 1981). A two-component mixing model clearly simplifies the nature of water routing through Alpine glaciers. However, there is strong evidence to suggest that this type of model does indeed describe many features of the subglacial drainage system (paper in preparation by M. Sharp and others).

We prefer to use the terminology, "quick flow" and "delayed flow", to describe the two major components. This better identifies the different residence times of the components in the subglacial drainage sytem, which are the result of different hydraulic conditions in the different parts of the system. Further, it allows both components to follow separate flowpaths prior to mixing and transit through the major conduits which terminate at the portal (paper in preparation by M. Sharp and others).

Quick flow pertains to waters in rapid transit through the hydroglacial system, predominantly through icewalled conduits (Röthlisberger, 1972) and basal channels. Delayed flow pertains to waters in slow transit through a distributed drainage system at the glacier bed (paper in preparation by M. Sharp and others), such as a linked-cavity system (Walder, 1986). Unlike temperate catchments, where "old" water or delayed flow may dominate peak run-off (Turner and others, 1990), dyetracing studies at Haut Glacier d'Arolla demonstrate that quick flow makes a significant contribution to the diurnal discharge maximum (paper in preparation by P.W. Nienow and others). These studies also demonstrate the existence of drainage systems with characteristically short $(<2 \mathrm{~h})$ and long $(>12 \mathrm{~h})$ residence times. Hence quick flow and delayed flow are pertinent descriptions of the two components.
Alpine glaciers may have an entirely distributed drainage sytem or a combined distributed-channel system, but they are unlikely to have only a channel system (Fowler, 1987). In the case of the combined system, the distributed system drains into the channel system, particularly during the height of the ablation season, and there is great potential for post-mixing chemical evolution of the bulk meltwaters via interactions with elevated suspended-sediment concentrations (Sharp, 1991). The seasonal growth of the channel system and the implications for suspended-sediment concentrations in bulk meltwaters have been reviewed by Sharp (1991), and an important observation is that suspendedsediment concentrations appear to be low when the quick-flow component is low. In general, delayed flow dominates bulk meltwater discharge early in the ablation season, when suspended-sediment concentrations are low, and the importance of quick flow increases as the ablation season progresses.

Quick flow and delayed flow are both derived mainly from surface-snow and ice melt, and the original solute content of these waters will be generally low (see below). Hence, the different composition of the components is derived from the differing types and the duration of chemical-weathering reactions that the waters undergo during transit through the hydroglacial system.

\section{A CONGEPTUAL MODEL FOR THE ACQUISIT- ION OF SOLUTE BY ALPINE GLACIAL MELT- WATERS}

Solute is defined as all ions, including base cations (e.g. $\left.\mathrm{Ca}^{2+}, \mathrm{Mg}^{2+}, \mathrm{K}^{+}, \mathrm{Na}^{+}\right)$, aqueous protons $\left(\mathrm{H}^{+}(\mathrm{aq})\right.$ ) and anions $\left(\mathrm{HCO}_{3}^{-}, \mathrm{SO}_{4}{ }^{2-}, \mathrm{NO}_{3}{ }^{-}, \mathrm{Cl}^{-}\right)$, and neutral species (e.g. $\mathrm{O}_{2}, \mathrm{~N}_{2}, \mathrm{CO}_{2}, \mathrm{H}_{4} \mathrm{SiO}_{4}$ ) dissolved in water (Stumm and Morgan, 1981). Solute acquisition (or chemical weathering) is therefore concerned with reactions which affect species in all phases: solid, liquid and gas. To date, the glaciological literature has given scant attention to the importance of dissolved gases and their impact on the rate and extent of chemical weathering.

Solute may be dervied from atmospheric deposition, either contained in snow or rain, or from dry deposition on to the catchment surface (Barrie, 1991; Cadle, 1991). The first-derived snowmelt or rain-snowmelt mixture is more concentrated than that derived from leached snow cover, since solute from snow readily fractionates into snowmelt and rainfall (Johannessen and Henriksen, 1978; Jones and others, 1989; Tranter, 1991). Thereafter, snowand ice-melt is relatively pure, as confirmed by studies which have sampled supraglacial meltwaters in ice-walled channels near the glacier snout (Collins, 1978; Raiswell and Thomas, 1984; Tranter and Raiswell, 1991). The snow line retreats up-glacier as the ablation season proceeeds, and therefore snowpack leaching occurs later at higher altitudes. However, much of the solute found in the bulk meltwaters emerging at the portal is acquired by chemical weathering in subglacial environments (Souchez and Lemmens, 1987). Exceptions to this rule are species such as $\mathrm{NO}_{3}{ }^{-}$and $\mathrm{O}_{2}$ (aq), which have a predominantly atmospheric source. 
The potential for meltwaters to acquire solute in subglacial locales is greatest if there is slow transit of waters through an environment which promotes relatively rapid rates of chemical weathering. This type of subglacial environment is most likely to be found in distributed drainage sytems, such as the linked cavity system, where (i) there is a copious supply of freshly comminuted rock flour, (ii) the rock flour contains reactive minerals, such as carbonates and sulphides, (iii) the residence time of the meltwater is relatively long, and (iv) relatively rapid sulphide oxidation provides a proton supply. The ubiquitous minerals, calcite (a carbonate) and pyrite (a sulphide), are important sources of solute to meltwaters, despite being usually a minor component of the bedrock, since their dissolution kinetics are orders of magnitude more rapid than those of most other rockforming minerals (Tranter, 1982).

By contrast, chemical weathering in open channels is more likely to be driven by slower gaseous diffusion of $\mathrm{CO}_{2}$ into solution, since the trace amounts of sulphide and carbonate present in the glacial flour will have been largely dissolved in the distributed system. As will become evident, chemical weathering in full conduits may be limited because of the restricted access to a source of gaseous $\mathrm{CO}_{2}$.

\section{SOURGES OF BASE GATIONS}

Meltwaters acquire base cations via two major types of reaction, simple dissolution and acid hydrolysis. Simple dissolution reactions do not involve protons. Rather, they involve solids such as sea salt, derived from dry deposition on to the catchment surface or aerosol scavenged by snowfall, or evaporitic minerals in the bedrock, such as halite and gypsum (Raiswell and others, 1980). Usually, these reactions supply minor quantities of base cations to Alpine glacial meltwaters because of the continental location of the Alps and the lithology of the bedrock. However, if sources of evaporitic minerals are found in glacial catchments, they are likely to have a marked impact on the composition of meltwater.

Instead, most base cations usually result from the broad class of reactions known as acid hydrolysis (Raiswell and others, 1980). These reactions require a source of aqueous protons, which are exchanged for base cations from the rock-flour surface (see Equations (1) and (2)).

$$
\begin{array}{r}
\mathrm{CaAl}_{2} \mathrm{Si}_{2} \mathrm{O}_{8}(\mathrm{~s})+2 \mathrm{H}^{+}(\mathrm{aq}) \\
\text { anorthite (Ca-feldspar) } \\
\rightleftharpoons \mathrm{Ca}^{2+}(\mathrm{aq})+\mathrm{H}_{2} \mathrm{Al}_{2} \mathrm{Si}_{2} \mathrm{O}_{8}(\mathrm{~s}) \\
\quad \text { weathered feldspar surfaces }
\end{array}
$$

$$
\mathrm{CaCO}_{3}(\mathrm{~s})+\mathrm{H}^{+}(\mathrm{aq}) \rightleftharpoons \mathrm{Ca}^{2+}(\mathrm{aq})+\mathrm{HCO}_{3}^{-}(\mathrm{aq}) \text {. }
$$

calcite

The aqueous protons required for acid hydrolysis are derived from two main sources. The first is the dissociation of dissolved $\mathrm{CO}_{2}$, derived via diffusion, either directly from the atmosphere or indirectly from gas bubbles within melting ice:

$$
\mathrm{CO}_{2}(\mathrm{aq})+\mathrm{H}_{2} \mathrm{O}(\mathrm{aq}) \rightleftharpoons \mathrm{H}^{+}(\mathrm{aq})+\mathrm{HCO}_{3}^{-}(\mathrm{aq}) \text {. }
$$

The second source of protons is the oxidation of sulphides, such as pyrite $\left(\mathrm{FeS}_{2}\right)$, which are commonly found in the bedrock of Alpine glacier basins in trace amounts:

$$
\begin{gathered}
\quad 4 \mathrm{FeS}_{2}(\mathrm{~s})+15 \mathrm{O}_{2}(\mathrm{aq})+14 \mathrm{H}_{2} \mathrm{O}(\mathrm{aq}) \\
\text { pyrite } \\
\rightleftharpoons 16 \mathrm{H}^{+}(\mathrm{aq})+4 \mathrm{Fe}(\mathrm{OH})_{3}(\mathrm{~s})+8 \mathrm{SO}_{4}{ }^{2-}(\mathrm{aq}) . \\
\quad \text { ferric oxyhydroxides }
\end{gathered}
$$

Oxidation of sulphides normally requires the presence of $\mathrm{O}_{2}$, but under certain circumstances, e.g. in water-filled subglacial channels where anaerobic conditions may develop, other oxidizing agents, such as $\mathrm{NO}_{3}{ }^{-}$, may be used (paper in preparation by M. Sharp and others). More detailed accounts of the mechanism and rate of pyrite oxidation may be found in Singer and Stumm (1970) and Toran and Harris (1989).

Protons may also be derived from the dissolution of acids, either scavenged from the atmosphere by snow and rain or dry-deposited on to the glacier surface (Barrie, 1991; Cadle, 1991). This is particularly the case early in the melt season, when snowmelt is usually most acidic (Tranter, 1991).

$$
\mathrm{H}_{2} \mathrm{SO}_{4}(\mathrm{~s}) \rightleftharpoons 2 \mathrm{H}^{+}(\mathrm{aq})+\mathrm{SO}_{4}{ }^{2-}(\mathrm{aq})
$$

acid sulphate aerosol

$$
\mathrm{HNO}_{3}(\mathrm{~s}) \rightleftharpoons \mathrm{H}^{+}(\mathrm{aq})+\mathrm{NO}_{3}^{-}(\mathrm{aq})
$$

acid nitrate aerosol

The major base cation in glacial meltwaters is $\mathrm{Ca}^{2+}$ (Raiswell, 1984), which partially reflects the relatively rapid rate of dissolution of $\mathrm{Ca}^{2+}$ from silicate and aluminosilicate minerals relative to other base cations (Lerman, 1979), and the fact that carbonate dissolution is a major source of dissolved ions to delayed flow (see below).

\section{THE SOURCE OF ANIONS}

The common acid anions, $\mathrm{Cl}^{-}, \mathrm{HCO}_{3}{ }^{-}, \mathrm{NO}_{3}{ }^{-}$and $\mathrm{SO}_{4}{ }^{2-}$, can be derived from a number of sources, as illustrated above, but it is normally safe to assume that $\mathrm{Cl}^{-}$and $\mathrm{NO}_{3}{ }^{-}$are derived mainly from the dissolution of sea-salt aerosol (Holland, 1978; Souchez and Lemmens, 1987) and acidic nitrate aerosol (see Equations (1) and (6)), respectively. The latter is true because significant numbers of $\mathrm{N}_{2}$-fixing bacteria are unlikely within the glacial system. By contrast, most $\mathrm{SO}_{4}{ }^{2-}$ is likely to be derived from the oxidation of sulphides in comminuted bedrock (Tranter and Raiswell, 1991). Smaller amounts are derived from the dissolution of atmospheric aerosol (Brown, 1991), as represented in Equation (5). Bicarbonate may be derived from two main sources, from the dissociation of atmospheric $\mathrm{CO}_{2}$ (see Equation (3)) and the dissolution of carbonates, such as calcite (see Equation (2)).

The two major anions in Alpine glacial meltwaters are $\mathrm{HCO}_{3}{ }^{-}$and $\mathrm{SO}_{4}{ }^{2-}$ (Souchez and Lemmens, 1987), because the dissociation of atmospheric $\mathrm{CO}_{2}$ and the oxidation of sulphides provide the bulk of the protons used to weather chemically carbonate, silicate and 
aluminosilicate minerals in glacial flour. Hence, the supply of atmospheric $\mathrm{CO}_{2}$ and $\mathrm{O}_{2}$ to meltwaters is a fundamental control on the rate and the extent of chemical weathering in glacial meltwaters.

\section{SURFACE EXCHANGE AND GARBONATION - DOMINANT REAGTIONS IN QUICK FLOW AND THE POST-MIXING CHEMICAL EVOLUTION OF BULK MELTWATERS}

Existing studies of chemical weathering in glacial environments have focused on so-called ion-exchange processes (Lorrain and Souchez, 1972; Lemmens and Roger, 1978; Souchez and Lemmens, 1987), which are relatively rapid reactions. We prefer to adopt the following nomenclature, since it gives a better description of the reaction mechanism. Ion exchange is the rapid, reversible exchange of ions between solution and a solid surface (Stumm and Morgan, 1981). This type of exchange is said to be non-specific, because no chemical bonds are formed between the adsorbed ion and the mineral surface (Parks, 1990). Cation exchange is the rapid, reversible exchange of positively charged ions. Ion and cation exchange, by definition, cannot add solute to meltwaters (cf. Lemmens and Roger, 1978; Drewry, 1986). These reactions simply modify the relative proportion of ions present in a fixed pool of dissolved ions. The initial reaction between water and freshly comminuted aluminosilicates or silicates usually involves a surface exchange of base cations for hydrogen ions (or protons) from solution (Wollast, 1967; Luce and others, 1972; Busenberg and Clemency, 1976; Lerman, 1979). Surface, rather than ion, exchange is the term used for this reaction because although the reaction is rapid (typically occurring within $3 \mathrm{~min}$; Busenberg and Clemency, 1976), it is largely irreversible (Garrels and Howard, 1956). The surface of the mineral may be physically altered during surface exchange (Casey and Bunker, 1990) rendering it difficult to replace (or exchange) the adsorbed protons for dissolved base cations (Garrels and Howard, 1956). This type of exchange is said to be specific, since a chemical bond is formed between the adsorbed ion and the mineral surface (Parks, 1990). Full and detailed accounts of adsorption phenomena can be found in Hochella and White (1990).

Surface exchange has a marked effect on the ability of the solution to dissolve $\mathrm{CO}_{2}$. The loss of protons from solution increases the $\mathrm{pH}$ and, as a consequence, markedly increases the quantity of dissolved $\mathrm{CO}_{2}$, $\mathrm{HCO}_{3}{ }^{-}$and $\mathrm{CO}_{3}{ }^{2-}$ that the solution can hold for a fixed partial pressure of carbon dioxide, $p \mathrm{CO}_{2}$ (see Fig. la). When isolated from the gas phase, the amount of dissolved $\mathrm{CO}_{2}$ in the solution, $\mathrm{CO}_{2}$ (aq), falls following surface exchange, since it is converted into $\mathrm{HCO}_{3}{ }^{-}$(see Equation (3)), as shown in Figure lb. Hence, $\mathrm{CO}_{2}$ from the gas phase, which may be the atmosphere or bubbles in the ice walls for example diffuses into solution until the $p \mathrm{CO}_{2}$ in the gas phase, and $\mathrm{CO}_{2}(\mathrm{aq})$ are in equilibrium (see Appendix). As $\mathrm{CO}_{2}$ diffuses into the solution, a large proportion dissociates into $\mathrm{HCO}_{3}^{-}$and $\mathrm{H}^{+}$(aq). These protons are usually rapidly removed from solution by surface exchange and the slower dissolution of the mineral
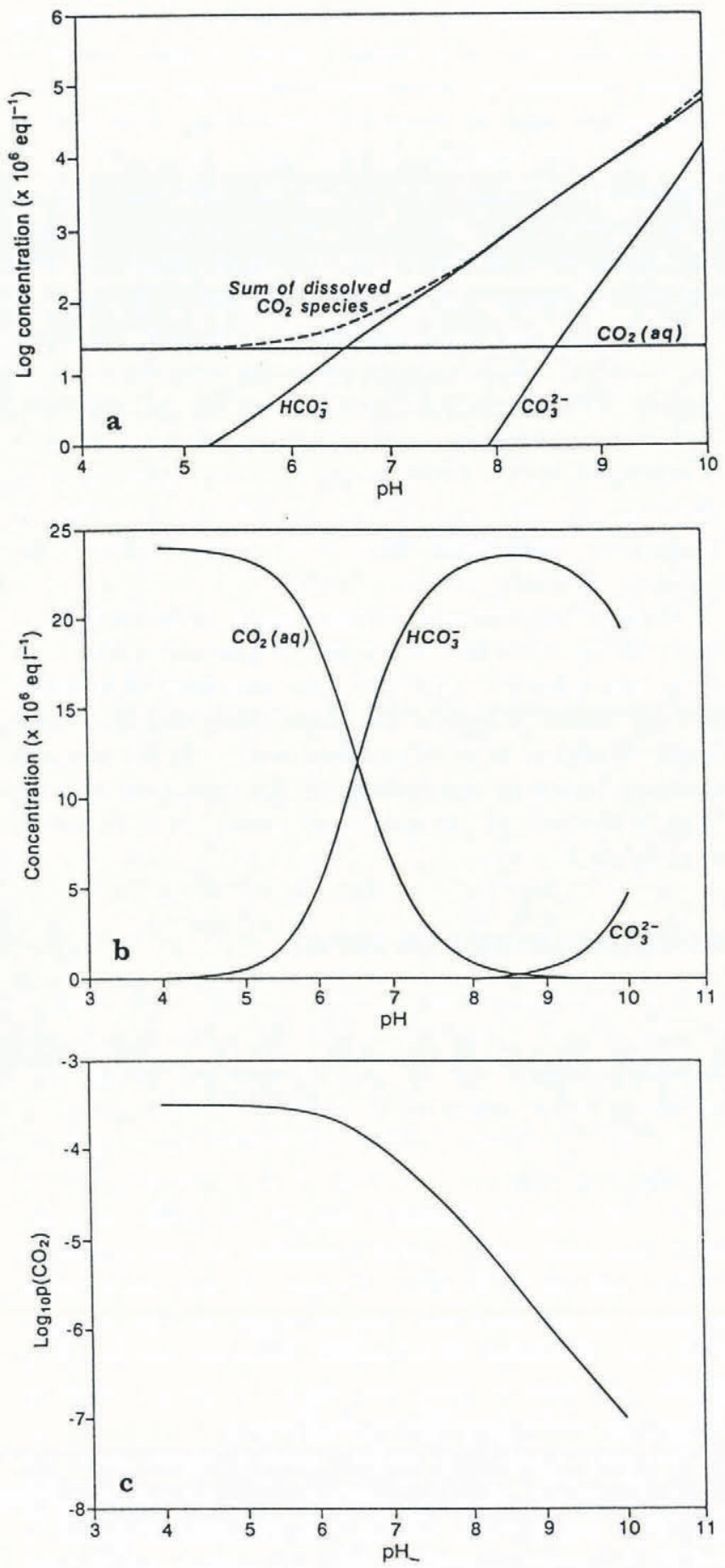

Fig. 1. a. The relationship between the sum of dissolved carbon dioxide species $\left(\mathrm{CO}_{2}(\mathrm{aq})+\mathrm{HCO}_{3}^{-}+\mathrm{CO}_{3}{ }^{2-}\right)$ and $\mathrm{pH}$. The ability of the solution to dissolve $\mathrm{CO}_{2}$ increases with increasing $\mathrm{pH}$ because $\mathrm{CO}_{2}(\mathrm{aq})$ dissociates into $\mathrm{HCO}_{3}^{-}$and $\mathrm{CO}_{3}{ }^{2-}$. The diagram was constructed by assuming that the solution is in equilibrium with a gas phase $p\left(\mathrm{CO}_{2}\right)$ of $10^{-3.5} \mathrm{~atm}$, that the Henry's law constant, $K_{\mathrm{H}}$, is $10^{-1.12}$ mol atm $\Gamma^{-1}$ and that the first and second dissociation constants for dissolved $\mathrm{CO}_{2}$ are $10^{-6.58}$ and $10^{-10.62}$ mol $\Gamma^{-1}$, respectively. These constants are for $T=0^{\circ} \mathrm{C}$ (Garrels and Christ, 1965). $b$. The effect of $\mathrm{pH}$ on the speciation of dissolved $\mathrm{CO}_{2}$. The sum of the dissolved species remains constant at $24 \mu e q \Gamma^{-1}$, i.e. no $\mathrm{CO}_{2}$ is allowed to diffuse into or out of solution. $c$. As the $\mathrm{pH}$ increases, $\mathrm{CO}_{2}(\mathrm{aq})$ is converted into $\mathrm{HCO}_{3}{ }^{-}$(or $\left.\mathrm{CO}_{3}{ }^{2-}\right)$ and the $\mathrm{p}\left(\mathrm{CO}_{2}\right)$ in the gas phase with which the solution is in equilibrium decreases (see Appendix). Equilibrium constants as in Figure 1a. 
lattice, and are largely replaced by base cations from the rock-flour surface. Alumina and silica are also released into solution by the dissolution of the mineral lattice (Chou and Wollast, 1984; Lasaga, 1984; Casey and Bunker, 1990). This type of "carbonation" reaction (Reynolds and Johnson, 1972) is most likely to occur in open channels or partially filled cavitities, where there is ample access to rock flour and gaseous $\mathrm{CO}_{2}$ (cf. full conduits and water-filled cavitites, where access to gaseous $\mathrm{CO}_{2}$ is limited). Hence, carbonation will largely be responsible for solute acquisition by quick flow, because there are no other significant sources of protons and sulphide oxidation is largely confined to the distributed system (see below).

Carbonation will also be largely responsible for the solute acquisition which occurs after the quick flow and delayed flow mix in the basal channel system (Raiswell and Thomas, 1984; Tranter and others, 1989) as confirmed by the non-conservative mixing properties of base cations and $\mathrm{HCO}_{3}{ }^{-}$relative to $\mathrm{SO}_{4}{ }^{2-}$ (paper in preparation by $M$. Sharp and others). Carbonation reactions therefore dominate the composition of bulk meltwaters when the proportion of quick flow is high and when post-mixing reactions add significant quantities of solute to solution.

\section{SOLUTE ACQUISITION AS A RESULT OF SUL- PHIDE OXIDATION - A DOMINANT CONTROL ON THE COMPOSITION OF DELAYED FLOW}

Protons may also be derived from the oxidation of suphides, such as pyrite (see Equation (6)). Sulphide oxidation is likely to liberate protons and $\mathrm{SO}_{4}{ }^{2-}$ (i.e. sulphuric acid) at or near the site of rock-flour generation, when the rock flour makes contact with waters containing suitable oxidizing agents (e.g. $\mathrm{O}_{2}$ ). Freshly comminuted rock flour is most likely to contain unaltered sulphide minerals, since sulphide oxidation is relatively rapid and goes to completion in the presence of suitable oxidizing agents (Moses and others, 1987). So, chemical weathering in the distributed system provides an additional proton source, which is largely limited by the oxygen content of the meltwater and the trace-sulphide content of the rock flour.

The protons liberated by sulphide oxidation are likely to be rapidly utilized by surface-exchange reactions and/ or carbonate dissolution at or near the site of rock-flour generation. Hence, base cations, rather than hydrogen ions, are the counter ions to $\mathrm{SO}_{4}{ }^{2-}$ in delayed flow (Tranter and Raiswell, 1991). Whereas the product of sulphide oxidation, $\mathrm{SO}_{4}{ }^{2-}$, can be leached from the comminuted rock flour by the delayed flow, the rock flour itself only seems to leave the distributed system in relatively high concentrations during active periods of channel growth (Collins, 1989; Sharp, 1991). Hence, we believe that reactive sulphides, either present as comminuted particles or close to the surface of the rock flour, will be exhausted within the distributed system, and are largely absent from rock flour transported from the distributed system into the channel system.

The assumption that $\mathrm{SO}_{4}{ }^{2-}$ is largely confined to the delayed flow (Tranter and Raiswell, 1991) is likely to be significantly in error only during the early ablation season, when relatively concentrated snowmelt may directly run off the glacier surface and mix with bulk meltwaters, consisting predominantly of delayed flow. Even if the suspended sediment contains weatherable sulphide, it is likely that this will be relatively slow to react, since the reactive sulphide would have been consumed within the distribution system and the remaining sulphide would have to be relatively inert to survive transport through the distributed system.

\section{OPEN- AND GLOSED-SYSTEM WEATHERING REGIMES - FINGERPRINTS OF THE DIFFER- ENT CHEMICAL-WEATHERING REACTIONS IN THE DISTRIBUTED AND CONDUIT/BASAL CHANNEL SYSTEMS}

A solution is said to be open when the $p\left(\mathrm{CO}_{2}\right)$ in the gas phase is in equilibrium with the amount of dissolved $\mathrm{CO}_{2}$ in the liquid phase (i.e. $p\left(\mathrm{CO}_{2}\right) \approx K_{\mathrm{H}}\left(\mathrm{CO}_{2}\right)(\mathrm{aq})-$ see the Appendix for the significance of $K_{\mathrm{H}}$ ). The system is said to be closed when this is not the case (i.e. $p\left(\mathrm{CO}_{2}\right)$ $\left.\neq K_{\mathrm{H}}\left(\mathrm{CO}_{2}\right)(\mathrm{aq})\right)$. Open- and closed-system weathering regimes are kinetic phenomena and depend on the rate at which $\mathrm{CO}_{2}$ diffuses into or out of solution relative to the rate of other chemical-weathering reactions (Raiswell, 1984; Raiswell and Thomas, 1984; Thomas and Raiswell, 1984).

If the rate of weathering is greater than the rate of proton supply, the resultant increase in $\mathrm{pH}$ induces gaseous $\mathrm{CO}_{2}$ diffusion into solution because the solution can hold additional $\left(\mathrm{CO}_{2}\right)(\mathrm{aq})$. We define this solution as a "low- $p\left(\mathrm{CO}_{2}\right)$ system". Conversely, a high- $p\left(\mathrm{CO}_{2}\right)$ system is one in which protons added to an open system

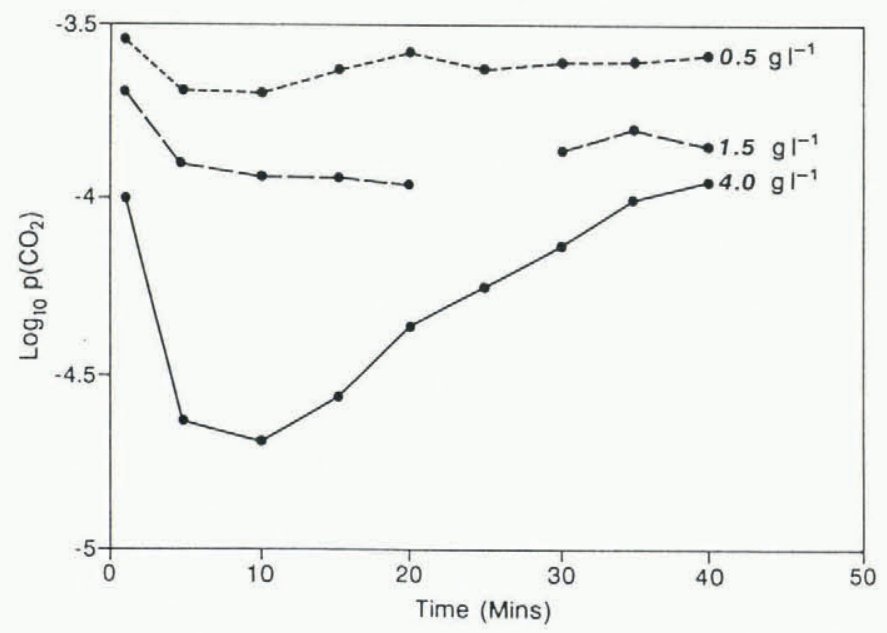

Fig. 2. The $p\left(\mathrm{CO}_{2}\right)$ of a mixture of $\mathrm{Na}$-feldspar and deionized water, as a function of time and rock: water ratio. These results were obtained by adding a known weight of crushed feldspar to 11 of deionized water in open contact with the atmosphere at $T=20^{\circ} \mathrm{C}$ (Tranter, 1982). Note that most values are below atmospheric $p\left(\mathrm{CO}_{2}\right)\left(=10^{-3.5} \mathrm{~atm}\right)$. When $p\left(\mathrm{CO}_{2}\right)$ is declining, the rate of weathering is greater than the rate of $\mathrm{CO}_{2}$ influx into the solution. The converse argument holds when $p\left(\mathrm{CO}_{2}\right)$ is rising. 

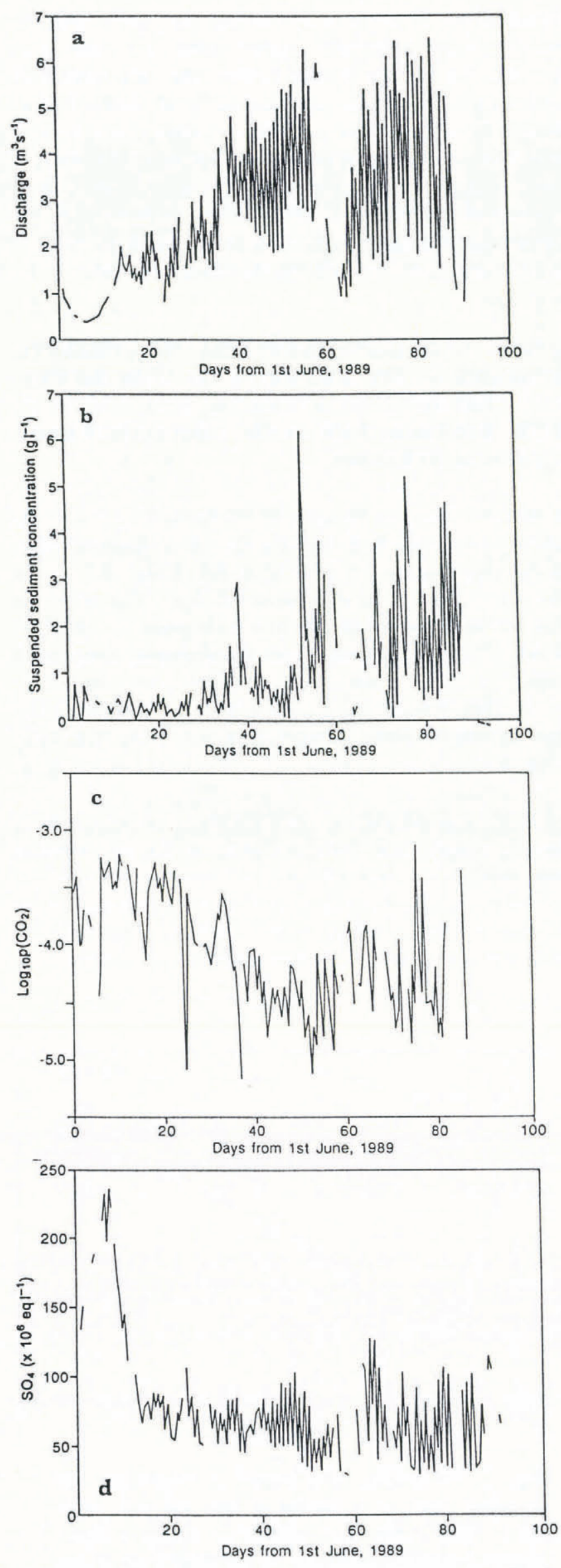

Fig. 3. The (a) discharge, (b) suspended-sediment concentration, (c) $p\left(\mathrm{CO}_{2}\right)$ and (d) sulphate concentration of meltwaters draining Haut Glacier d'Arolla during the 1989 ablation season. There is some evidence for a decrease in $p\left(\mathrm{CO}_{2}\right)$ as the discharge and suspendedsediment concentrations increase (Brown, 1991). are not rapidly consumed by weathering reactions, and $\mathrm{CO}_{2}$ (aq) attempts to diffuse out of solution since some $\mathrm{HCO}_{3}^{-}$is converted to $\mathrm{CO}_{2}(\mathrm{aq})$ by the additional protons.

Low- $p\left(\mathrm{CO}_{2}\right)$ systems are common when a large supply of reactive, comminuted rock is brought into contact with relatively pure water (see Fig. 2). The glacial analogue is when large quantities of dilute quick-flow waters mix with sediment-laden delayed flow at the height of the ablation season (Sharp, 1991; paper in preparation by P.W. Nienow and others; paper in preparation by M. Sharp and others). Given these circumstances, the rate of proton consumption is greater than the rate of gaseous diffusion of $\mathrm{CO}_{2}$ into solution, and $\left(\mathrm{CO}_{2}\right)$ (aq) remains below open-system values (see Fig. 3 ).

High- $p\left(\mathrm{CO}_{2}\right)$ systems may arise from three types of scenario. First, an input of protons to the drainage system may occur, so as to give a short-lived reduction in $\mathrm{pH}$, for example when acidic snowmelt mixes with a subglacial water body. We believe that this scenario is transient in most subglacial environments, since rock flour has a great capacity for adsorbing protons. Secondly, the freezing of a water body may result in an increase in $\left(\mathrm{CO}_{2}\right)(\mathrm{aq})$, since $\mathrm{CO}_{2}$ is not readily incorporated into the ice lattice. However, it seems unlikely that this mechanism of high $p\left(\mathrm{CO}_{2}\right)$ generation operates on any other than a local scale in most Alpine glaciers. Finally, neutralization of acidity by carbonates may produce high $\left(\mathrm{CO}_{2}\right)$ (aq), particularly in water-filled cavities or channels where there is only limited opportunity for the solution to degas.

Table 1. Estimates of the composition of delayed flow

$\begin{array}{llc}\text { Glacier } & \text { Gornergletscher } & \text { Haut Glacier } \\ \text { Species } & \text { (Tranter and } & \text { d'Arolla } \\ & \text { Raiswell, 1991) } & \text { (Brown, 1991) }\end{array}$

\begin{tabular}{llr}
\hline $\mathrm{Ca}^{2+}$ & $400-1200$ & $260-720$ \\
$\mathrm{HCO}_{3}{ }^{-}$ & $250-850$ & $290-600$ \\
$\mathrm{SO}_{4}{ }^{2-}$ & $320-1700$ & $86-430$ \\
\hline
\end{tabular}

Units of concentration are $\mu$ eq $1^{-1}$.

These compositions were derived following the method of Tranter and Raiswell (1991).

Waters of the delayed flow contain both high concentrations of $\mathrm{HCO}_{3}{ }^{-}$and $\mathrm{SO}_{4}{ }^{2-}$ (see Table 1). The following argument suggests that the delayed flow appears to exhibit high $p\left(\mathrm{CO}_{2}\right)$. Figure 4 demonstrates that the mass fraction of $\mathrm{SO}_{4}{ }^{2-}$ (defined as the ratio of $\mathrm{SO}_{4}{ }^{2-}$ to the sum of $\mathrm{SO}_{4}{ }^{2-}$ and $\mathrm{HCO}_{3}{ }^{-}$, where concentrations are in units of equivalents) in the bulk meltwaters draining Haut Glacier d'Arolla decreases as discharge increases. This suggests that delayed flow, which dominates at lower discharge, contains a higher mass fraction of $\mathrm{SO}_{4}{ }^{2-}$ than quick flow. Figure 5 suggests that the $p \mathrm{CO}_{2}$ of bulk meltwater increases as the mass 


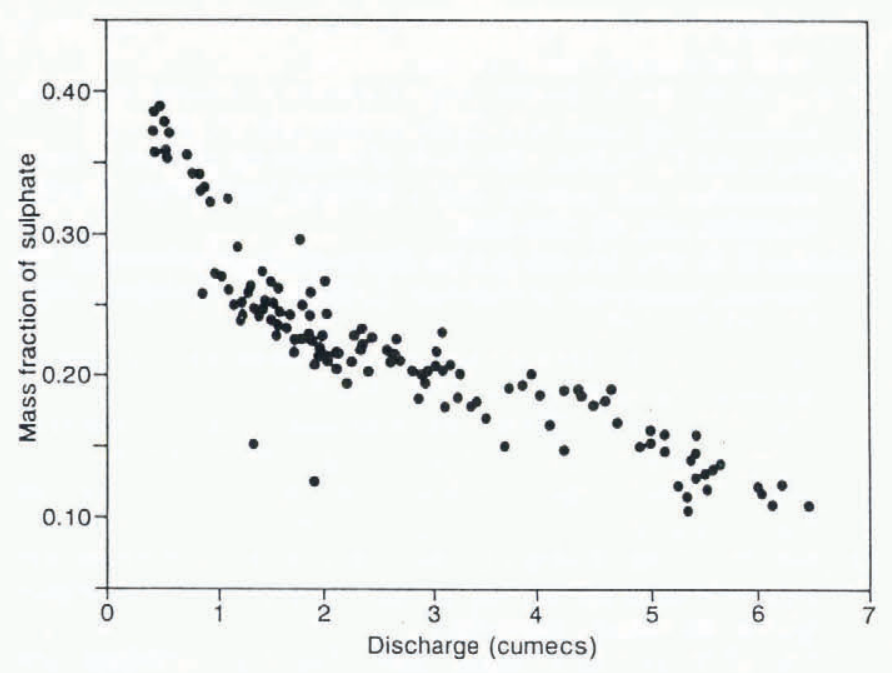

Fig. 4. The mass fraction of $\mathrm{SO}_{4}{ }^{2-}\left(\mathrm{SO}_{4}{ }^{2-} /\left(\mathrm{SO}_{4}{ }^{2-}+\right.\right.$ $\mathrm{HCO}_{3}{ }^{-}$) and where units are equivalents), as a function of discharge for bulk meltwaters draining Haut Glacier d'Arolla throughout the 1989 ablation season.

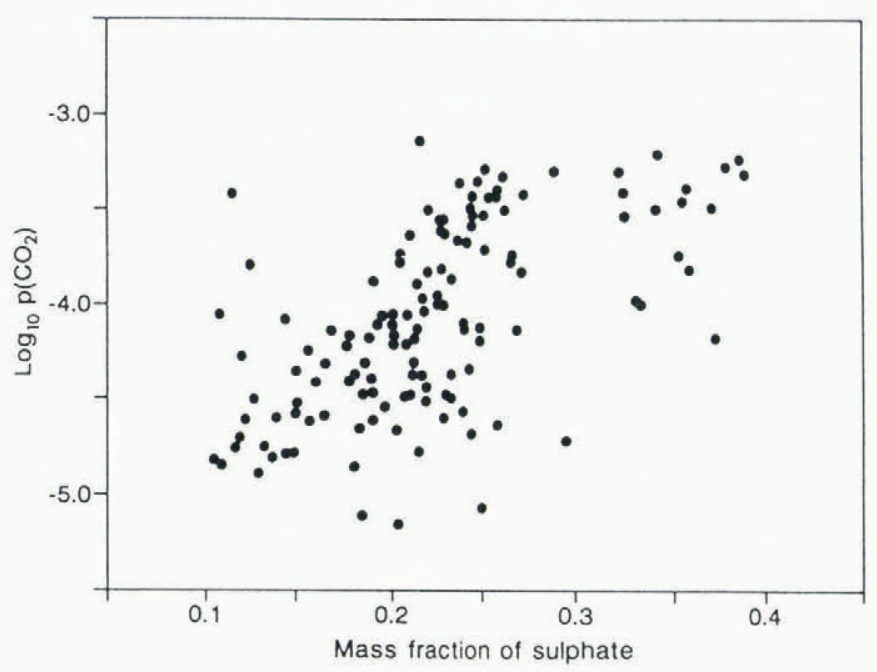

Fig. 5. The association of $p\left(\mathrm{CO}_{2}\right)$ with the mass fraction of $\mathrm{SO}_{4}{ }^{2-}$ for bulk meltwaters of Haut Glacier d'Arolla throughout the 1989 ablation season.

fraction of $\mathrm{SO}_{4}{ }^{2-}$ increases. Since bulk meltwaters dominated by delayed flow exhibit high $p\left(\mathrm{CO}_{2}\right)$, delayed flow is also likely to exhibit high $p\left(\mathrm{CO}_{2}\right)$.

The combination of high concentrations of $\mathrm{Ca}^{2+}$ $\mathrm{HCO}_{3}{ }^{-}-\mathrm{SO}_{4}{ }^{2-}$ in the delayed flow (see Table 1) in conjunction with elevated $p\left(\mathrm{CO}_{2}\right)$ values tends to suggest that the coupling of sulphide oxidation and carbonate dissolution are dominant controls on the composition of delayed flow, as illustrated by Equation (7). The high $p\left(\mathrm{CO}_{2}\right)$ is generated by the production of $\mathrm{HCO}_{3}{ }^{-}$on the righthand side of the equation.

$$
\begin{aligned}
& 4 \mathrm{FeS}_{2}(\mathrm{~s})+16 \mathrm{CaCO}_{3}(\mathrm{~s})+15 \mathrm{O}_{2}(\mathrm{aq})+14 \mathrm{H}_{2} \mathrm{O}(\mathrm{aq}) \\
& \text { pyrite calcite } \\
& \begin{array}{c}
\rightleftharpoons 16 \mathrm{Ca}^{2+}(\mathrm{aq})+16 \mathrm{HCO}_{3}{ }^{-}(\mathrm{aq})+8 \mathrm{SO}_{4}{ }^{2-}(\mathrm{aq}) \\
\quad+4 \mathrm{Fe}(\mathrm{OH})_{3}(\mathrm{~s}) .
\end{array}
\end{aligned}
$$

The resulting high $p\left(\mathrm{CO}_{2}\right)$ signature so generated may be diminished or lost as a consequence of post-mixing chemical-weathering reactions and degassing of bulk meltwaters in open channels (Raiswell, 1984). This helps to explain some of the scatter displayed in Figure 5.

\section{LOW $p\left(\mathrm{CO}_{2}\right)$ SIGNATURES IN BULK MELT- WATERS - A CONSEQUENCE OF POST-MIX- ING REACTIONS}

Figure 4 demonstrates that bulk meltwaters at high discharge have a low mass fraction of $\mathrm{SO}_{4}{ }^{2-}$. Figure 5 shows that these waters have low- $p\left(\mathrm{CO}_{2}\right)$ characteristics. It is likely that the low- $p\left(\mathrm{CO}_{2}\right)$ signature is attributable to post-mixing weathering reactions, of the type illustrated in Figure 2 and described by Equations (1) and (2). Quick flow passing through ice-walled conduits has little opportunity to gain access to rock flour and hence will maintain an open-system $p\left(\mathrm{CO}_{2}\right)$ or a slightly lower $p\left(\mathrm{CO}_{2}\right)$, depending on the amount of rock-water contact that is possible. By contrast, bulk meltwaters in basal channels clearly gain access to and transport large quantities of rock flour, which is capable of undergoing chemical weathering (Tranter and others, 1989). Therefore, it is most likely that post-mixing reactions promote the low- $p\left(\mathrm{CO}_{2}\right)$ signatures of bulk meltwaters at high discharge.

\section{ARE DELAYED FLOW AND QUICK-FLOW COM- POSITIONS CONSTANT THROUGHOUT THE ABLATION SEASON?}

The above conceptual model of solute acquisition by Alpine glacial meltwaters stresses that dissolution and gas-diffusion kinetics are important controls on the composition of the two major discharge components and their post-mixing chemical evolution. These reaction kinetics are dependent on the residence time of waters within the channel and distributed systems, the supendedsediment concentration and the access of an atmospheric gas supply, factors which clearly change during the ablation season as the glacial drainage system evolves (paper in preparation by M. Sharp and others). Hence, it is most probable that the composition of each component will likewise evolve during the ablation season. A similar line of reasoning also suggests that the extent of postmixing chemical evolution of the meltwaters will vary throughout the season.

\section{CONCLUSIONS}

Solute acquisition in glacial meltwaters results from reactions which involve species in all phases: solid, aqueous and gaseous. Typically, chemical weathering involves two coupled reactions, such that dissolved gases affect the nature and rate of solute acquisition. Surfaceexchange reactions in open channels and conduits promote net solute acquisition as a result of influx of gaseous $\mathrm{CO}_{2}$ - so-called carbonation reactions. Oxidation of sulphides and the dissolution of carbonate is a characteristic coupled reaction of the distributed system.

Waters of the delayed flow are relatively concentrated 
because they flow slowly through the distributed system, where they are in contact with large quantities of relatively reactive, recently comminuted rock flour, and importantly, because there is a renewable supply of protons available to sustain prolonged chemical weathering. These protons may be derived from the input of acidic snowmelt early in the ablation season, but oxidation of sulphides is the more sustainable source throughout the season. The coupling of sulphide oxidation and carbonate dissolution may impart a high$p\left(\mathrm{CO}_{2}\right)$ signature to the delayed flow, as well as relatively high concentrations of $\mathrm{Ca}^{2+}, \mathrm{HCO}_{3}{ }^{-}$and $\mathrm{SO}_{4}{ }^{2-}$.

Quick flow waters are dilute because of their short residence time in the conduit system and because the supply of protons is limited to slow gaseous diffusion of $\mathrm{CO}_{2}$ into solution. Quick flow waters may have opensystem or low- $p\left(\mathrm{CO}_{2}\right)$ signatures, depending on the extent of chemical weathering they undergo and the degree to which the channelized systems is in contact with a gaseous phase.

Mixing of the components in the channelized system may allow post-mixing chemical weathering of rock flour, fuelled by protons supplied from influxing $\mathrm{CO}_{2}$ and acidic snowmelt (paper in preparation by $\mathrm{M}$. Sharp and others). Ultimately, the $p\left(\mathrm{CO}_{2}\right)$ exhibited by bulk meltwaters is a balance between the rate at which $\mathrm{CO}_{2}$ can diffuse in or out of solution and the rate of proton consumption by chemical weathering. Hence, when suspended-sediment concentrations are high, the $p\left(\mathrm{CO}_{2}\right)$ will be low and, when suspended-sediment concentrations are low, bulk meltwaters take on higher $p\left(\mathrm{CO}_{2}\right)$ values characteristic of the delayed flow, or approach open-system values if degassing of $\mathrm{CO}_{2}$ can occur.

Given these kinetic controls on the composition of each component, it is unlikely that the components maintain a constant composition over the ablation season.

\section{ACKNOWLEDGEMENTS}

This paper arises from work undertaken in association with the U.K. Natural Environment Research Council grant No. GR3.7004A and U.K. NERC Studentship No. GT4/88/AAB $/ 56$.

\section{REFERENCES}

Barrie, L. A. 1991. Snow formation and processes in the atmosphere that influence its chemical composition. In Davies, T. D., M. Tranter and H. G. Jones, eds. Seasonal snowpacks; processes of compositional change. Berlin, Springer-Verlag, 1-20.

Bindschadler, R. 1983. The importance of pressurized subglacial water in separation and sliding at the glacier bed. 7. Glaciol., 29(101), 3-19.

Brown, G. H. 1991. Solute provenance and transport pathways in Alpine glaciers. (Ph.D. thesis, University of Southampton.)

Brown, G.H. and M. Tranter. 1990. Hydrograph and chemograph separation of bulk meltwaters draining the Upper Arolla glacier, Valais, Switzerland. International Association of Hydrological Sciences Publication 193 (Symposium at Lausanne 1990 - Hydrology in Mountainous Regions. I. Hydrological Measurements; the Water Cycle), $429-437$.

Busenberg, E. and C. V. Clemency. 1976. The dissolution kinetics of feldspars at $25^{\circ} \mathrm{C}$ and 1 atms $\mathrm{CO}_{2}$ partial pressure. Geochim. Cosmochim. Acta, 40, 41-49.

Cadle, S. H. 1991. Dry deposition to snowpacks. In Davies, T.D., M.
Tranter and H.G. Jones, eds. Seasonal snowpacks; processes of compositional change. Berlin, Springer-Verlag, 21-66.

Casey, W.H. and B. Bunker. 1990. Leaching of mineral and glass surfaces during dissolution. Reviews in Mineralogy, 23, 397-426.

Chou, L. and R. Wollast. 1984. Study of weathering of albite at room temperature and pressure with a fluidized bed reactor. Geochim. Cosmochim. Acta, 48, 2205-2217.

Collins, D. N. 1978. Hydrology of an Alpine glacier as indicated by the chemical composition of meltwater. Z. Gletscherkd. Glazialgeol., 13(1) 2), 1977, 219-238.

Collins, D. N. 1979a. Hydrochemistry of meltwaters draining from an Alpine glacier. Arct. Alp. Res., 11(3), 307-324.

Collins, D.N. 1979b. Quantitative determination of the subglacial hydrology of two Alpine glaciers. J. Glaciol., 23(89), 347-362.

Collins, D. N. 1981. Seasonal variation of solute concentration in melt waters draining from an Alpine glacier. Ann. Glaciol., 2, 11-16.

Collins, D. N. 1989. Seasonal development of subglacial drainage and suspended sediment delivery to melt waters beneath an Alpine glacier. Ann. Glaciol., 13, 45-50.

Collins, D.N. and G.J. Young. 1981. Meltwater hydrology and hydrochemistry in snow- and ice-covered mountain catchments. Nord. Hydrol., 12(4-5), 319-334.

Drewry, D. 1986. Glacial geologic processes. London, Edward Arnold.

Fowler, A. C. 1987. Sliding with cavity formation. J. Glaciol., 33(115), 255-267.

Garrels, R. M. and C. L. Christ. 1965. Solutions, minerals and equilibria. San Francisco, Freeman Cooper.

Garrels, R. M. and P. Howard. 1956. Reactions of feldspar and mica with water at low temperature and pressure. Clays Clay Miner., 6, 6888.

Gurnell, A. M. 1987. Suspended sediment. In Gurnell, A. M. and M.J. Clark, eds. Glacio-fluvial sediment transfer. New York, John Wiley, 305354.

Gurnell, A. M. and C. R. Fenn. 1984. Flow separation, sediment source areas and suspended sediment transport in a pro-glacial stream. Catena Supplement 5, 109-119.

Hochella, M.F. and A.F. White, eds. 1990. Mineral-water interface geochemistry. Reviews in Mineralogy, 23.

Holland, H. D. 1978. The chemistry of atmospheres and oceans. New York, Wiley-Interscience.

Iken, A. 1981. The effect of the subglacial water pressure on the sliding velocity of a glacier in an idealized numerical model. 7 . Glaciol., 27(97), 407-421.

Iken, A., H. Röthlisberger, A. Flotron and W. Haeberli. 1983. The uplift of Unteraargletscher at the beginning of the melt season - a consequence of water storage at the bed? f. Glaciol., 29(101), 28-47.

Johannessen, M. and A. Henriksen. 1978. Chemistry of snow meltwater: changes in concentration during melting. Water Resour. Res., 14(4), 615-619.

Jones, H. G., M. Tranter and T. D. Davies. 1989. The leaching of strong acid anions from snow during rain-on-snow events: evidence for two component mixing. International Association of Hydrological Sciences Publication 179 (Symposium at Baltimore 1987 - Atmospheric Deposition), 239-250.

Lasaga, A. G. 1984. Chemical kinetics of water-rock interactions. J. Geophys. Res., 89(B6), $4009-4025$.

Lemmens, M. M. and M. Roger. 1978. Influence of ion-exchange on dissolved load of Alpine meltwaters. Earth Surface Processes, 3, 179 187.

Lerman, A. 1979. Geochemical processes: water and sediment environments. New York, Wiley-Interscience.

Lliboutry, L. 1983. Modifications to the theory of intraglacial waterways for the case of subglacial ones. 7. Glaciol., 29(102), 216-226.

Lorrain, R. D. and R.A. Souchez. 1972. Sorption as a factor in the transport of major cations by meltwaters from an Alpine glacier. Quat. Res., 2(2), 253-256.

Luce, R. W., R. W. Barlett and G. A. Parks. 1972. Dissolution kinetics of magnesium silicates. Geochim. Cosmochim. Acta, 36, 35-50.

Moses, C. O., D. K. Nordstrom, J.S. Herman and A. L. Mills. 1987. Aqueous pyrite oxidation by dissolved oxygen and by ferric ions. Geochim. Cosmochim. Acta, 51, 1561-1571.

Oerter, H., H. Behrens, G. Hibsch, W. Rauert and W. Stichler. 1980. Combined environmental isotope and electrical conductivity investigations at the runoff of Vernagtferner (Oetztal Alps). Mater. Glyatsiol. Issled. Khron. Obsuzhdeniya 39, 157-161.

Parks, G. A. 1990. Surface energy and adsorption at mineral/water interfaces: an introduction. Reviews in Mineralogy, 23, 133-175.

Raiswell, R. 1984. Chemical models of solute acquisition in glacial melt waters. 7. Glaciol., 30(104), 49-57. 
Raiswell, R. and A. G. Thomas. 1984. Solute acquisition in glacial melt waters. I. Fjallsjökull (south-east Iceland): bulk melt waters with closed-system characteristics. F. Glaciol., 30(104), 35-43.

Raiswell, R., P. Brimblecombe, D. Dent and P.S. Liss. 1980. Environmental chemistry. London, Edward Arnold.

Reynolds, R.C. and N. M. Johnson. 1972. Chemical weathering in the temperate glacial environment of the Northern Cascade Mountains. Geochim. Cosmochim. Acta, 36, 537-534.

Röthlisberger, H. 1972. Water pressure in intra- and subglacial channels. F. Glaciol., 11(62), 177-203.

Sharp, M. 1991. Hydrological influences from meltwater quality data: the unfulfilled potential. Proceedings of the BHS 3rd National Hydrological Symposium, Southampton, 5.1-5.8.

Singer, P. C. and W. Stumm. 1970. Acidic mine drainage: the ratedetermining step. Science, 167, 1121-1123.

Souchez, R. A. and M. M. Lemmens. 1987. Solutes. In Gurnell, A. M. and H.J. Clarke, eds. Glacio-fluvial sediment transfer. New York, John Wiley, 285-303.

Stumm, W. and J.J. Morgan. 1981. Aquatic chemistry. Second edition. New York, Wiley-Interscience.

Thomas, A. G. and R. Raiswell. 1984. Solute acquisition in glacial melt waters. II. Argentière (French Alps): bulk melt waters with opensystem characteristics. F. Glaciol., 30(104), 44-48.

Toran, L. and R. F. Harris. 1989. Interpretation of sulfur and oxygen isotopes in biological and abiological sulfide oxidation. Geochim. Cosmochim. Acta, 53, 2341-2348.

Tranter, M. 1982. Controls on the chemical composition of Alpine glacial meltwaters. (Ph.D. thesis, University of East Anglia.)

Tranter, M. 1991. Controls on the composition of snowmelt. In Davies, T. D., M. Tranter and H. G. Jones, eds. Seasonal snowpacks; processes of compositional change. Berlin, Springer-Verlag, 241-271.

Tranter, M. and R. Raiswell. 1991. The composition of the englacial and subglacial component in bulk meltwaters draining the Gornergletscher. 7. Glaciol., 37(125), 59-66.

Tranter, M., R. Raiswell and R. A. Mills. 1989. Chemical weathering reactions in Alpine glacial meltwaters. In Miles, D. L., ed. Proceedings of the 6th International Symposium on Water-Rock Interaction, Malvern, 1989. Rotterdam, Balkema, 687-690.

Turner, R.S. and 7 others. 1990. Watershed and lake processes affecting surface water acid-base chemistry. Acidic Deposition: State of Science and Technology. National Acid Precipitation Assessment Program Report 10. Washington, DC, Government Printing Office.

Walder, J. S. 1986. Hydraulics of subglacial cavities. F. Glaciol., 32(112), $439-445$.
Weertman, J. and G. E. Birchfield. 1983. Basal water film, basal water pressure, and velocity of traveling waves on glaciers. $\mathcal{J}$. Glaciol., 29(101), 20-27.

Wollast, R. 1967. Kinetics of alteration of K-feldspar in buffered solutions at low temperature. Geochim. Cosmochim. Acta, 31, 635-648.

The accuracy of references in the text and in this list is the responsibility of the authors, to whom queries should be addressed.

\section{APPENDIX}

Equilibrium between $\mathrm{CO}_{2}$ in the gas phase and the dissolved phase is dependent on the Henry's Law constant, $K_{\mathrm{H}}$, as described by Equation (A1).

$$
\mathrm{CO}_{2}(\mathrm{~g}) \approx K_{\mathrm{H}} \mathrm{CO}_{2}(\mathrm{aq}) \text {. }
$$

Since $\left(\mathrm{CO}_{2}\right)(\mathrm{g}) \approx p\left(\mathrm{CO}_{2}\right)$,

$$
p\left(\mathrm{CO}_{2}\right)=\left(\mathrm{CO}_{2}\right)(\mathrm{aq}) / K_{\mathrm{H}} .
$$

It is important to remember that this situation pertains to $\left(\mathrm{CO}_{2}\right)$ (aq) being in equilibrium with $p\left(\mathrm{CO}_{2}\right)$. Now imagine the situation in which $\mathrm{CO}_{2}$ has been added to the solution, so that the new quantity, $\left(\mathrm{CO}_{2}\right)^{*}(\mathrm{aq})$, is in excess of $\left(\mathrm{CO}_{2}\right)$ (aq). It follows from Equation (A2) that the apparent gas-phase partial pressure of $\mathrm{CO}_{2}$ with which the solution is in equilibrium, $p\left(\mathrm{CO}_{2}\right)^{*}$, is likewise greater that $p\left(\mathrm{CO}_{2}\right)$. So, the solution degasses until a new equilibrium between gas phase and dissolved phase $\mathrm{CO}_{2}$ is reached.

The terminology, "high- $p\left(\mathrm{CO}_{2}\right)$ system", derives from the fact that the solution is in apparent equilibrium with a higher $p\left(\mathrm{CO}_{2}\right)$ than actually exists. A similar line of reasoning gives rise to the converse case of the low$p\left(\mathrm{CO}_{2}\right)$ system. 